\title{
Compatibility between Calpurnia aurea leaf extract, attraction aggregation, and attachment pheromone and entomopathogenic fungus Metarhizium anisopliae on viability, growth, and virulence of the pathogen
}

\author{
Paulin Nana ${ }^{1,2}$, Nguya K. Maniania ${ }^{1}$, Rosebella O. Maranga ${ }^{2}$, Hamadi I. Boga ${ }^{2}$, \\ Helen L. Kutima ${ }^{2}$ and Jacobus N. Eloff \\ ${ }^{1}$ International Centre of Insect Physiology and Ecology (icipe), P.O. Box 30772-00100, Nairobi, GPO, Kenya \\ ${ }^{2}$ Jomo Kenyatta University of Agriculture and Technology, P.O. Box 62000-00200, City Square, Nairobi, Kenya \\ ${ }^{3}$ Department of Paraclinical Sciences, Faculty of Veterinary Science, University of Pretoria, Private Bag X04, \\ Onderstepoort, 0110, South Africa
}

Corresponding author : Nguya K. Maniania Email: nmaniania@icipe.org

\begin{abstract}
Metarhizium anisopliae sensu stricto (ss) (Metsch.) Sorok. isolate ICIPE 07 is being developed as biopesticide for the control of ticks. In addition, leaf extracts of Calpurnia aurea Benth, and the attraction aggregation and attachment pheromone (AAAP) are being used as ticks' attractant. The three agents are being considered for use in combination in an autodissemination approach, whereby ticks that are attracted to semiochemicals are infected with the inoculum. Experiments were therefore conducted to evaluate in vitro the compatibility between $C$. aurea, AAAP, and the M. anisopliae on vegetative growth, conidial production, and spore viability. Calpurnia aurea leaf extract was compatible with the fungus at all the concentrations tested, whereas AAAP inhibited all the fungal growth parameters. The virulence of $M$. anisopliae formulated in emulsifiable extracts of $C$. aurea was also tested against different developmental stages of Rhipicephalus appendiculatus in laboratory bioassays. No significant differences in virulence were observed between $M$. anisopliae applied alone and M. anisopliae formulated in different concentrations of $C$. aurea leaf extracts. These results suggest that $C$. aurea leaf extracts is compatible with $M$. anisopliae and could be mixed together for "spot-spray" treatments as lowcost and environmental-friendly technology to control ticks in grazing field, while AAAP should be used separately.
\end{abstract}

Keywords : Compatibility, Biocontrol agents, Metarhizium anisopliae, Calpurnia aurea, Rhipicephalus appendiculatus

\section{Introduction}

Rhipicephalus appendiculatus Neumann, 1901 (Acari: Ixodidae) known as cattle tick, is a serious pest in livestock production. It is one of the world's most widely distributed and damaging tick (Watt and Walker 2000; Ndhlovu et al. 2009). It transmits a wide range of devastating, even fatal diseases of livestock including East cost fever, Corridor disease, and theileriosis (Razmi et al. 2003), which are considered to be an important constraint to the development of the livestock industry in Africa (Zahid Iqbal et al. 2006).

Current tick control methods still heavily depend on the application of synthetic acaricides such as organophosphates (malathion and comaphous). Safety risks for humans and domestic animals 
to this strategy include environmental contamination (Pell et al. 2001), impacts on non-target organisms (Schulze et al. 2001), human health problems due to chemical residues in food products (Ostfeld et al. 2006), and the development of resistance in ticks (Graf et al. 2004). More environmental-friendly alternatives such as biological control based on the use entomopathogenic fungi are being developed (Feng et al. 2004; Faria and Wraight 2007; Maniania et al. 2007; Nchu et al. 2010). Metarhizium anisopliae sensu stricto (Metsch.) Sorokin (Hypocreales: Clavicipitaceae) is among the entomopathogenic fungi that has received considerable attention in recent years (Briggs et al. 2006; Abolins et al. 2007; Tavassoli et al. 2008; Nchu et al. 2010).

Inundative release is the most common method widely used for the introduction of entomopathogens into the environment for the control of arthropod pests (Lacey and Goettel 1995) including ticks (Kaaya and Hassan 2000). However, a new approach is being investigated, whereby ticks that are attracted to a semiochemicals, such as attraction-aggregation-attachment pheromone (AAAP), are infected with entomopathogenic fungi (Nchu et al. 2009). Recently, Nchu et al. (2010) reported reduction of Amblyomma variegatum Fabricius (Acari: Ixodidae) populations in the field by infecting them with conidia of $M$. anisopliae applied in semiochemical-baited traps.

A number of ethnoveterinary plants have been reported to attract ticks of the genera Rhipicephalus (Hassan et al. 1994; Zorloni et al. 2010). Recently, Nana et al. (2010) demonstrated the attraction of R. pulchellus and R. appendiculatus to leaf extracts of Calpurnia aurea Benth (Fabaceae). It can be therefore envisaged to use the leaf extracts of this plant in combination with entomopathogenic fungi in a kairomone-baited trap system for autodissemination of fungal conidia in the field. However, plant extracts can affect entomopathogenic fungi negatively (Duarte et al. 1992; Malo 1993; Marques et al. 2004; Depieri et al. 2005) and subsequently, the control of the target pest (Akbar et al. 2005; Mohan et al. 2007). For instance, Depieri et al. (2005) reported that aqueous seed extract from Azadirachta indica A. Juss. (Meliaceae) (Neem) reduced conidial vegetative growth and production of Beauveria bassiana (Bals.) Vuill. (Hypocreales: Cordycipitaceae). On the other hand, some plant extracts have been reported to have synergistic effect on insect mortality (Mohan et al. 2007). The present study was, therefore, initiated to evaluate in vitro the effects of the leaf extract of $C$. aurea and of AAAP on growth parameters (radial growth and spore production) of the fungus M. anisopliae. We also investigated whether the virulence of $M$. anisopliae formulated in emulsifiable extract of $C$. aurea against different developmental stages of R. appendiculatus can be affected.

\section{Materials and methods}

\section{Plant material}

Calpurnia aurea leaves were collected in September 2007 in the Lowveld National Botanical Garden in Nelspruit, South Africa. Identification was performed at the Botanical Garden 
Herbarium, Pretoria, South Africa, where a voucher specimen was deposited under the number 3206. Leaves were dried in the shade and ground to a fine powder with a McSalib mill (Eloff 1999). The powder was stored in a closed glass container in the dark.

\section{Preparation of $\boldsymbol{C}$. aurea emulsifiable formulation}

The dry powder $\left(100 \mathrm{~g}\right.$ ) of C. aurea was macerated in $500 \mathrm{ml}$ of corn oil (Elianto ${ }^{\circledR}$, BIDCO Oil Refineries Ltd., Nairobi, Kenya) and $100 \mathrm{ml}$ distilled water for $6 \mathrm{~h}$ and then placed in a water bath at $40^{\circ} \mathrm{C}$ for $2 \mathrm{~h}$. The mixture was later filtered, and the different concentrations $(12.5,25,50$ and $100 \mathrm{mg} / \mathrm{ml}$ ) were obtained by serial dilution.

\section{Preparation of the pheromone}

Attraction-aggregation-attachment pheromone (AAAP) was prepared by mixing $0.2 \mathrm{mg}$ of ortho-nitrophenol, $0.1 \mathrm{mg}$ of methyl salicylate, and $0.8 \mathrm{mg}$ of nonanoic acid. The synthetic compounds were obtained from Sigma-Aldrich Chemie GmbH, Steinheim, Germany. Concentrations of $0.005,0.01$, and $0.02 \mathrm{mg} / \mathrm{ml}$ were used. Concentration of $0.02 \mathrm{mg} / \mathrm{ml}$ was previously shown to significantly attract R. appendiculatus (Nchu et al. 2009).

\section{Tick colony}

Different stages (larvae, nymphs, and adults) of R. appendiculatus ticks were used. They were obtained from the icipe's Animal and Quarantine Rearing Unit. The ticks were counted in batches of 20. Each batch was then placed in a vial with a cotton wool plug, and the ticks were stored in darkness at RH $75 \%$ and $25 \pm 2{ }^{\circ} \mathrm{C}$ until further use.

\section{Fungus}

Metarhizium anisopliae isolate ICIPE 07 used in this study was obtained from the icipe Arthropod Germplasm Centre. The strain was isolated from an engorged female A. variegatum collected from Rusinga Island, Kenya, in 1996 and was previously reported to be virulent against R. appendiculatus (Kaaya et al. 1996). The fungus was stored under mineral oil before being used in the experiment. The virulence of the isolated fungus was restored by passage through adult R. appendiculatus. Conidia were produced on long rice as substrate using Milner's bag process (Nchu et al. 2009).

\section{Mycelia dry weight assessment}

A conidial suspension $(0.1 \mathrm{ml})$ titrated $1 \times 10^{6}$ conidia $\mathrm{ml}^{-1}$ was spread-plated on SDA medium plates. Plates were then incubated at $25 \pm 2^{\circ} \mathrm{C}$ for three days to obtain mycelial mats (Dimbi et al. 2004). The unsporulated mycelial mats were then cut into round agar plugs using a 4-mm diameter cork borer and each agar plug was then transferred singly onto the center of a $90-\mathrm{mm}-$ diameter Petri dish containing fresh SDA agar amended with 1.2, 2.5, 5, and 10\% C. aurea. In the case of AAAP, agar was amended with concentrations of $0.005,0.01$, and $0.02 \%$ of AAAP. In the controls, plates were amended with respective solvents. Four Petri dishes (replicates) per treatment were sealed with Parafilm and incubated in complete darkness at $25 \pm 2^{\circ} \mathrm{C}$ for 7 days. After 1 week, the mycelial mat was harvested with sterile spatula, placed in sterile Petri dishes 
containing filter paper. The initial weight of the filter paper was recorded. The Petri dishes were kept in hot air in oven at $50-60^{\circ} \mathrm{C}$ for $30 \mathrm{~min}$, and the final weight of the fungal mat along with the filter paper was recorded immediately. The difference between the final and initial weight was considered as dry weight of mycelium.

\section{Radial fungal growth}

Agar plugs were obtained using the same technique as described above. Each agar plug was then transferred onto the center of a fresh SDA plate amended with $0,1.2,2.5,5$, and 10\% emulsifiable extracts of $C$. aurea or $0.005,0.01$, and $0.02 \%$ AAAP as described above. Plates were sealed with Parafilm and incubated upside down in complete darkness at $25 \pm 2{ }^{\circ} \mathrm{C}$. Radial growth was recorded daily for 6 days using two cardinal diameters, through two orthogonal axes previously drawn on the bottom of each Petri dish to serve as a reference. The experiment was replicated four times.

\section{Spore production assessment}

Agar plugs obtained as described earlier were transferred onto the center of a fresh SDA plate amended with emulsifiable extracts of $C$. aurea or AAAP at the same concentrations as above. Plates were then incubated at $25 \pm 2{ }^{\circ} \mathrm{C}$ for 7 days. The sporulated mycelial mats were then cut from the culture plates into round agar plugs using a 4-mm-diameter cork borer. Each agar plug was then transferred singly onto the universal bottle containing $10-\mathrm{ml}$ sterile distilled water with $0.02 \%$ sterile Tween 20 , and vortexed for $5 \mathrm{~min}$. Conidial concentration was determined using a Neubauer counting chamber. The experiment was replicated four times.

\section{Virulence of $M$. anisopliae formulated in emulsifiable extract of $C$. aurea on different developmental stages of $\mathbf{R}$. appendiculatus}

Conidia of $M$. anisopliae isolate ICIPE 07 were harvested from a 3-week-old culture by scrapping the surface of sporulating culture. Conidia were suspended in sterile distilled water containing $0.05 \%$ Triton X-100 in universal bottles with glass beads. Different concentrations of emulsifiable extract $(0,1.25,2.5,5$, and $10 \%)$ were added to the suspension and vortexed for $5 \mathrm{~min}$ to produce homogenous suspension. Ten milliliters $(10 \mathrm{ml})$ of a standard concentration of $1.0 \times 10^{9}$ conidia $\mathrm{ml}^{-1}$ was prepared for each of the treatments and sprayed on larvae, nymphs, and adults of R. appendiculatus using the Burgerjon's spray tower (Burgerjon 1950) (INRA, Dijon, France). Each treatment group had two different controls: one received sterile distilled water containing $0.05 \%$ Triton X-100 only and the other received sterile distilled water containing $0.05 \%$ Triton X-100 with $10 \%$ emulsifiable extract without fungus. Twenty ticks were used for each treatment, and the experiment was replicated five times. Tick-tests were transferred in the vials $\left(1.5 \times 12 \mathrm{~cm}^{2}\right)$ and maintained in an incubator at $25 \pm 2{ }^{\circ} \mathrm{C}$ and $75 \% \mathrm{RH}$. Mortality was recorded daily for 14 days. Dead ticks were immediately removed and surfacesterilized with $2.5 \%$ sodium hypochlorite and $70 \%$ alcohol, rinsed twice in sterile distilled water, and then placed into 9-cm-diameter Petri dishes lined with moistened filter paper to allow the growth of fungus on the cadaver. The viability of conidia was tested before any bioassay by

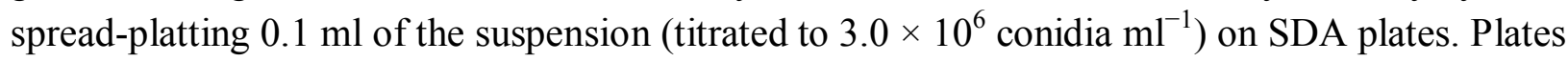


were then incubated at $25 \pm 2^{\circ} \mathrm{C}$ for $18 \mathrm{~h}$. Sterile microscope cover slip was then placed on each plate, and the percentage of germination was determined by counting 100 spores for each plates.

\section{Data analysis}

Compatibility between the fungus and semiochemicals was calculated using the formula proposed by Alves et al. (1998) to classify chemical products according to their toxicity to entomopathogenic fungi in vitro. This classification is based on calculations of the $\mathrm{T}$ factor, which relates vegetative growth (VG) and sporulation values (conidiogenesis) (SP) to the control $(\%): \mathrm{T}=[20(\mathrm{VG})+80(\mathrm{SP})] / 100$. In this model, values for vegetative growth (MDW) and sporulation count (SC) are given in relation to the control (100\%). "T" values between 0 and 30 classify products as very toxic; from 31 to 45 as toxic; from 46 to 60 , moderately toxic; and above 60, products are considered compatible with the fungus being studied. Analysis of variance (ANOVA procedure of SAS (2001)) was used to analyze percentage germination, radial growth, and mortality data. Percentage mortality (at 14 day post-treatment) was also adjusted for natural mortality in controls using Abbott (1925) formula before analysis and was then analyzed using two-way analysis of variance for a completely randomized design. Tukey test was used for post hoc analysis. A value of $\mathrm{P}<0.05$ was considered significant.

Table 1 : Effects of emulsifiable formulation of leaf extract of Calpurnia aurea on average ( \pm SD) radial growth, mycelial dry weight, conidial yield, and viability of Metarhizium anisopliae isolate ICIPE 07

\begin{tabular}{|c|c|c|c|c|c|}
\hline \multirow{2}{*}{$\begin{array}{l}\text { Emulsifiable leaf } \\
\text { extract/concentration }\end{array}$} & \multicolumn{2}{|c|}{ Colony diameter (mm) } & \multirow{2}{*}{$\begin{array}{l}\text { Mycelial dry } \\
\text { weight (mg) }\end{array}$} & \multirow{2}{*}{$\begin{array}{l}\text { Yield }\left(\times 10^{8}\right. \\
\left.\text { conidia } \mathrm{m}^{-1}\right)\end{array}$} & \multirow{2}{*}{$\begin{array}{l}\text { (\%) conidial } \\
\text { germination }\end{array}$} \\
\hline & $\begin{array}{l}3 \text { Day post- } \\
\text { inoculation } \\
(\mathrm{mm})\end{array}$ & $\begin{array}{l}6 \text { Day post- } \\
\text { inoculation } \\
(\mathrm{mm})\end{array}$ & & & \\
\hline Control & $17.2 \pm 1.0 \mathrm{a}$ & $33.0 \pm 0.5 \mathrm{a}$ & $81.1 \pm 1.1 \mathrm{a}$ & $11.2 \pm 1.7 \mathrm{a}$ & $98.4 \pm 1.7 \mathrm{a}$ \\
\hline $\mathrm{SDA}^{*}+1.2 \%$ & $15.2 \pm 1.0 \mathrm{a}$ & $31.4 \pm 1.1 \mathrm{a}$ & $74.9 \pm 7.6 \mathrm{a}$ & $11.1 \pm 0.6 \mathrm{a}$ & $97.2 \pm 1.1 \mathrm{a}$ \\
\hline $\mathrm{SDA}+2.5 \%$ & $16.8 \pm 1.7 \mathrm{a}$ & $32.2 \pm 0.5 \mathrm{a}$ & $78.0 \pm 5.1 \mathrm{a}$ & $10.6 \pm 1.4 \mathrm{a}$ & $98.4 \pm 2.8 \mathrm{a}$ \\
\hline $\mathrm{SDA}+5 \%$ & $17.2 \pm 1.5 \mathrm{a}$ & $31.4 \pm 0.5 \mathrm{a}$ & $80.5 \pm 12.8 \mathrm{a}$ & $10.8 \pm 0.8 \mathrm{a}$ & $97.8 \pm 2.6 \mathrm{a}$ \\
\hline $\mathrm{SDA}+10 \%$ & $16.8 \pm 1.0 \mathrm{a}$ & $31.8 \pm 0.5 \mathrm{a}$ & $75.2 \pm 9.7 \mathrm{a}$ & $9.7 \pm 4.8 \mathrm{a}$ & $97.8 \pm 2.1 \mathrm{a}$ \\
\hline F value & 2.06 & 2.85 & 0.59 & 0.27 & 0.26 \\
\hline $\mathrm{P}$ value & 0.12 & 0.06 & 0.67 & 0.89 & 0.89 \\
\hline
\end{tabular}

Means followed by the same letter on same column are not significantly different by ANOVA $(\mathrm{P}>0.05)$

* Sabouraud dextrose agar 


\section{Results}

Effects of emulsifiable formulation of leaf extract of $C$. aurea on radial growth, mycelial dried weight, conidial yield, and viability of $M$. anisopliae ICIPE 07

Emulsifiable formulation of $C$. aurea leaf extract at all the concentrations did not affect the vegetative growth, conidial yield, mycelia dry weight and conidial viability of the $M$. anisopliae compared to the control (Table 1). On the other hand, AAAP significantly reduced the colony diameters, mycelial dry weight and conidial yield of $M$. anisopliae at all the concentrations tested (Table 2). Emulsifiable formulation of $C$. aurea was highly compatible with fungus at tested dose $<10 \%$ and compatible at the concentration of $10 \%$ (Table 3 ). AAAP was toxic to $M$. anisopliae at $0.005 \%$ concentration and very toxic at 0.01 and $0.02 \%$ (Table 4 ).

Table 2 : Effects of AAAP on average $( \pm$ SD) radial growth, mycelial dry weight, conidial yield, and viability of Metarhizium anisopliae ICIPE 07

\begin{tabular}{|c|c|c|c|c|c|}
\hline \multirow{2}{*}{$\begin{array}{l}\text { AAAP* } \\
\text { concentrations }\end{array}$} & \multicolumn{2}{|c|}{ Colony diameter $(\mathrm{mm})$} & \multirow{2}{*}{$\begin{array}{l}\text { Mycelial dry } \\
\text { weight (mg) }\end{array}$} & \multirow{2}{*}{$\begin{array}{l}\text { Yield } \\
\left(\times 10^{8} \text { conidia } \mathrm{m}^{-1}\right)\end{array}$} & \multirow{2}{*}{$\begin{array}{l}(\%) \text { conidial } \\
\text { germination }\end{array}$} \\
\hline & $\begin{array}{l}3 \text { Days post- } \\
\text { inoculation }(\mathrm{mm})\end{array}$ & $\begin{array}{l}6 \text { Days post- } \\
\text { inoculation }(\mathrm{mm})\end{array}$ & & & \\
\hline $\mathrm{SDA}+0 \%$ & $16.4 \pm 1.5 \mathrm{a}$ & $31.6 \pm 0.5 a$ & $77.9 \pm 1.3 \mathrm{a}$ & $10.6 \pm 1.5 \mathrm{a}$ & $99.0 \pm 1.0 \mathrm{a}$ \\
\hline $\mathrm{SDA}+0.005 \%$ & $6.6 \pm 1.0 \mathrm{~b}$ & $16.8 \pm 1.1 \mathrm{~b}$ & $8.3 \pm 1.1 \mathrm{~b}$ & $3.9 \pm 0.5 b$ & $13.2 \pm 16.0 \mathrm{~b}$ \\
\hline $\mathrm{SDA}+0.01 \%$ & $6.8 \pm 1.0 \mathrm{~b}$ & $16.6 \pm 1.5 b$ & $7.9 \pm 1.0 \mathrm{~b}$ & $0.4 \pm 0.4 b$ & $10.0 \pm 12.5 b$ \\
\hline $\mathrm{SDA}+0.02 \%$ & $6.8 \pm 2.0 \mathrm{~b}$ & $14.2 \pm 1.1 b$ & $6.7 \pm 1.2 b$ & $0.0 \pm 0.0 \mathrm{~b}$ & $0.0 \pm 0.0 \mathrm{~b}$ \\
\hline F value & 56.24 & 239.68 & 4278.45 & 166.79 & 101.99 \\
\hline $\mathrm{P}$ value & 0.0001 & 0.0001 & 0.0001 & 0.0001 & 0.0001 \\
\hline
\end{tabular}

Means followed by the same letter on the same column are not significantly different by Tukey test $(\mathrm{P}<0.05)$

* Attraction aggregation attachment pheromone 
Table 3 : Values and compatibility classification of various concentrations of emulsifiable extract from Calpurnia aurea with Metarhizium anisopliae following the classification of Alves et al. (1998)

\begin{tabular}{|l|l|l|}
\hline Emulsifiable plant extract & M. anisopliae \\
\hline & “T" values & Classification \\
\hline SDA $+1.25 \%$ & 96.3 & HC \\
\hline SDA $+2.5 \%$ & 94.9 & HC \\
\hline SDA $+5 \%$ & 96.5 & HC \\
\hline SDA $+10 \%$ & 87.9 & C \\
\hline
\end{tabular}

HC highly compatible, C compatible

Table 4 : Values and compatibility classification of various concentrations of AAAP on Metarhizium anisopliae isolate following the classification of Alves et al. (1998)

\begin{tabular}{|l|l|l|}
\hline AAAP concentrations & M. anisopliae \\
\hline & “T” values & Classification \\
\hline SDA $+0.005 \%$ & 31.5 & T \\
\hline SDA $+0.01 \%$ & 5.4 & VT \\
\hline SDA $+0.02 \%$ & 1.7 & VT \\
\hline
\end{tabular}

T toxic, VT very toxic

\section{Virulence of $M$. anisopliae formulated in emulsifiable extract of $C$. aurea on different developmental stages of $R$. appendiculatus}

In viability tests, approx. $98 \%$ of conidia germinated. The mean mortalities in the controls were $1.7,2.8$, and $2.3 \%$ in larvae, nymphs, and adults, respectively (Table 5). M. anisopliae alone induced mortalities of 72,77 and $100 \%$ in adults, nymphs, and larvae, respectively. Similar trends were observed at each dose tested with the combination fungus - $C$. aurea. However, mortality rates varied according to the developmental stage. For instance, mortality rate of $100 \%$ was observed in larvae, of 74.8-79.1\% in nymphs, and 68.9-74.1\% in adults (Table 5). No significance difference in virulence was observed between $M$. anisopliae applied alone and $M$. anisopliae formulated in different concentrations of $C$. aurea extract. All the ticks that died in fungus-treated treatments developed mycosis (data not shown). 
Table 5 : Virulence of Metarhizium anisopliae (Ma) formulated in emulsifiable extract of Calpurnia aurea on different developmental stages of Rhipicephalus appendiculatus

\begin{tabular}{|l|c|c|c|}
\hline Treatments & \multicolumn{2}{|c|}{ Mortality (mean \% \pm SD) } \\
\hline & Larvae & Nymphs & Adults \\
\hline Control (no extract, no fungus) & $1.7 \pm 0.8 \mathrm{a}$ & $2.8 \pm 0.9 \mathrm{a}$ & $2.3 \pm 1.8 \mathrm{a}$ \\
\hline Control (10\% extract no fungus) & $2.5 \pm 4.0 \mathrm{a}$ & $1.9 \pm 1.0 \mathrm{a}$ & $3.2 \pm 0.7 \mathrm{a}$ \\
\hline Ma $10^{9}+0 \%$ & $100.0 \pm 0.0 \mathrm{~b}$ & $77.3 \pm 7.5 \mathrm{~b}$ & $72.5 \pm 5.6 \mathrm{~b}$ \\
\hline Ma $10^{9}+1.25 \%$ & $100.0 \pm 0.0 \mathrm{~b}$ & $79.1 \pm 9.2 \mathrm{~b}$ & $70.8 \pm 7.6 \mathrm{~b}$ \\
\hline Ma $10^{9}+2.5 \%$ & $100.0 \pm 0.0 \mathrm{~b}$ & $74.8 \pm 9.7 \mathrm{~b}$ & $74.1 \pm 8.5 \mathrm{~b}$ \\
\hline Ma $10^{9}+5 \%$ & $100.0 \pm 0.0 \mathrm{~b}$ & $75.7 \pm 9.5 \mathrm{~b}$ & $68.9 \pm 9.9 \mathrm{~b}$ \\
\hline Ma $10^{9}+10 \%$ & $100.0 \pm 0.0 \mathrm{~b}$ & $74.9 \pm 9.8 \mathrm{~b}$ & $69.7 \pm 6.2 \mathrm{~b}$ \\
\hline F value & 2952.26 & 74.82 & 85.21 \\
\hline P value & 0.0001 & 0.0001 & 0.0001 \\
\hline
\end{tabular}

Means followed by the same letter in the same column are not significantly different by Tukey test $(\mathrm{P}<0.05)$

\section{Discussion}

We have demonstrated that combination of emulsifiable extract from $C$. aurea with $M$.

anisopliae did not affect fungal growth parameters, namely, germination, radial growth, mycelial dried weight, and conidial yield regardless of the concentrations. Similar results were reported with extracts from Ocimum sanctum Linn. (Lamiaceae) with M. anisopliae (Borgio et al. 2008). Compatibility between the plant extract and fungal germination is necessary since germination is the first step in infection process (Roberts and Humber 1981). For instance, Hirose et al. (2001) reported that neem oil had negative effect on B. bassiana, inhibiting germination (45.3\%), colony diameter $(36.6 \%)$, and conidiogenesis $(84.9 \%)$. The use of incompatible plant extracts may therefore inhibit the development and reproduction of the pathogens, affecting pest control (Malo 1993).

Although the larval stage was more susceptible than nymphal and adult stages, conidia of $M$. anisopliae formulated in emulsifiable extract of $C$. aurea did not affect the virulence of the pathogen against the different developmental stages of R. appendiculatus. Differential susceptibility among different developmental stages in ticks has already been reported by many workers (Kaaya et al. 1996; Samish et al. 2001; Angelo et al. 2010). Conidia of M. anisopliae formulated in emulsifiable leaf extract of $C$. aurea did not result in any synergism effect against 
tick as reported in the case of B. bassiana and neem against Spodoptera litura Fabricius (Mohan et al. 2007).

Contrary to $C$. aurea emulsifiable extract, AAAP significantly inhibited all the growth parameters of $M$. anisopliae. This inhibition could be due to individual or combined effects of nonanoic acid and synthetic phenolic compounds that are part of the tick pheromone (Maranga et al. 2003). For instance, nonanoic acid produced by Trichoderma spp. has been reported to inhibit spore germination and mycelia growth of two cocoa pathogens (Anedja et al. 2005). On the other hand, phenolic compounds have been documented also to inhibit the growth of entomopathogenic fungi (Lopez-Llorca and Olivares-Bernabeu 1997). These results suggest that conidia of M. anisopliae cannot be mixed with AAAP but used separately (Nchu et al. 2009, 2010).

Since emulsifiable formulation of $C$. aurea does not have any effect on M. anisopliae, it can, therefore, be mixed with fungal conidia and spot-sprayed in grazing field while AAAP should be used separately in baited trap as reported by Nchu et al. (2010).

\section{Acknowledgments}

The first author received fellowship from the Bioscience Eastern and Central Africa Network (BecANet) and the Canadian International Development Agency (CIDA). The authors wish to thank BecANet, CIDA, icipe, and the curator of the Lowveld National Botanical Garden, who gave permission for the collection of plant material. The authors also extend their gratitude to the late Dr. A. Chabi, icipe, for reviewing the manuscript, and Ms Elizabeth Ouna and Ms Barbara Obonyo for their technical assistance.

\section{References}

Abbott WS (1925) A method of computing the effectiveness of an insecticide. J Econ Entomol $18: 265-267$

Abolins S, Thind B, Jackson V, Luke B, Moore D, Wall R, Taylor MA (2007) Control of sheep scab mite Psoroptes ovis in vivo and in vitro using fungal pathogens. Vet Parasitol 148:310-317 Akbar W, Lord JC, Nechols JR, Loughin TM (2005) Efficacy of Beauveria bassiana for red flour beetle when applied with plant essential oils or in mineral oil and organosilicone carriers. J Econ Entomol 98:683-688

Alves SB, Moino Jr, Almeida JEM (1998) Produtos fitossanitarios entomopatogenos, p 217-238. In: Alves SB (ed) Contrôle microbiano de insetos. Piracicaba, FEALQ, p 1163

Anedja M, Gianfagna TJ, Hebbar PK (2005) Trichoderma harzianum produces nonanoic acid, an inhibitor of spore germination and mycelia growth of two cacao pathogens. PMPP 67:304-307 Angelo IC, Fernandes EKK, Bahiense TC, Pernotto WMS, Moraes APR, Terra ALM, Bittencourt VREP (2010) Efficiency of Lecanicillium lecanii to control the tick Rhipicephalus microplus. Vet Parasitol 172:317-322

Borgio JF, Bency BJ, Sharma N (2008) Compatibility of Metarhizium anisopliae (Metsch.) Sorok. with Ocimum sanctum Linn. (Tulsi) (Lamiaceae) extracts. Ethnobotanical Leaflets 12:698-704 
Briggs LL, Colwell DD, Wall R (2006) Control of the cattle louse Bovicola bovis with the fungal pathogen Metarhizium anisopliae. Vet Parasitol 142:344-349

Burgerjon A (1956) Pulvérisation de poudrage au laboratoire par des préparations pathogènes insecticides. Ann Epiphyt 4:675-684

Depieri RA, Martinez SS, Jr OA Menezes (2005) Compatibility of the fungus Beauveria bassiana (Bals.) Vuill. (Deuteromycetes) with extracts of Neem seeds and leaves and the emulsifiable oil. Neotrop Entomol 34:601-606

Dimbi S, Maniania NK, Lux SA, Mueke JM (2004) Effect of constant temperatures on germination, radial growth and virulence of Metarhizium anisopliae to three species of African tephritid fruit flies. Biocontrol 49:83-94

Duarte A, Menendez JM, Triguero N (1992) Estudio preliminar sobre la compatilidad de Metarhizium anisopliae com algunos plaguicidas quimicos. Rev Baracoa 22:31-39

Eloff JN (1999) It is possible to use herbarium specimens to screen for antimicrobial components in some plants. J Ethnopharmacol 67:355-360

Faria MR, Wraight SP (2007) Mycoinsecticides and mycoacaricides: a comprehensive list with worldwide coverage and international classification of formulation types. Biol Control 43:237256

Feng MG, Pu XY, Ying SH, Wang YG (2004) Field trials of an oil-based emulsifiable formulation of Beauveria bassiana conidia and low application rates of imidacloprid for control of false-eye leafhopper Empoasca vitis in southern China. Crop Prot 23(6):489-496

Graf JF, Gogolewski R, Leach-Bing N, Sabatini GA, Molento MB, Bordin EL, Arantes GJ (2004) Tick control: an industry point of view. Parasitology 129:427-442

Hassan SM, Dipeolu OO, Malonza MM (1994) Natural attraction of livestock ticks by the leaves of shrub. Trop Anim Prod 26:87-91

Hirose E, Nerves PMOJ, Zequi JAC, Martins LH, Paralta CH, AJr Moino (2001) Effect of biofertilizers and neem oil on the entomopathogenic fungi Beauveria bassiana (Bals.) Vuill. and Metarhizium anisopliae (Metsch.) Sorok. Braz Arch Biol Technol 44:409-423

Kaaya GP, Hassan S (2000) Entomogenous fungi as promising biopesticides for tick control. Exp Appl Acarol 24(12):913-926

Kaaya GP, Mwangi EN, Ouna EA (1996) Prospects for biological control of livestock ticks, Rhipicephalus appendiculatus and Amblyomma variegatum, using the entomogenous fungi Beauveria bassiana and Metarhizium anisopliae. J Invertebr Pathol 67:15-20

Lacey LA, Goettel MS (1995) Current developments in microbial control of insect pests and prospects for the early 21 st century. Entomophaga 40:3-27

Lopez-Llorca LV, Olivares-Bernabeu C (1997) Growth inhibition of nematophagous and entomopathogenic fungi by leaf litter and soil containing phenols. Mycol Res 101:691-697 Malo AR (1993) Estudio sobre la compatibilidad del hongo Beauveria bassiana (Bals.) Vuill. Con formulaciones commerciales de funguicidas e insecticidas. Rev Colomb Entomol 19:151158

Maniania NK, Nchu F, Ekesi S (2007) Fungal pathogen for biocontrol of ticks. In: Ekesi S, Maniania NK (eds) Use of entomopathogenic fungi in biological pest management. Research Signpost, Kerala, pp 275-294

Maranga RO, Hassanali A, Kaaya GP, Mueke JM (2003) Attraction of Amblyomma variegatum (ticks) to the attraction-agregation-attachment-pheromone with or without carbon dioxide. Exp Appl Acarol 29:121-130 
Marques RP, Monteiro AC, Pereira GT (2004) Growth, esporulation and viability of entomopathogenic fungi under mediums with differents Nim oil (Azadirachta indica) concentrations. Ciência Rural 34:1675-1680

Mohan MC, Reddy NP, Uma K, Devi UK, Kongara R, Sharma HC (2007) Growth and insect assays of Beauveria bassiana with neem to test their compatibility and synergism. Biocontrol Sci Techn 17:1059-1069

Nana P, Maniania NK, Maranga RO, Boga HI, Kutima HL, Nchu F, Eloff JN (2010) Attraction response of adult Rhipicephalus appendiculatus and Rhipicephalus pulchellus (Acari: Ixodidae) ticks to extracts from Calpurnia aurea (Fabaceae). Vet Parasitol 174:124-130

Nchu F, Maniania NK, Toure A, Hassanali A, Eloff JN (2009) The use of a semiochemical bait to enhance exposure of Amblyomma variegatum (Acari: Ixodidae) to Metarhizium anisopliae (Ascomycota: Hypocreales). Vet Parasitol 160(3-4):279-284

Nchu F, Maniania NK, Hassanali A, Eloff JN (2010) Performance of a Metarhizium anisopliaetreated semiochemical-baited trap in reducing Amblyomma variegatum populations in the field. Vet Parasitol 169(3-4):367-372

Ndhlovu DN, Makaya PV, Penzhorn BL (2009) Tick infestation, and udder and teat damage in selected cattle herds of Matabeland South, Zimbabwe. Onderstepoort J Vet Res 76(2):235-248 Ostfeld RS, Price A, Hornbostel VL, Benjamin AB, Keesing F (2006) Controlling ticks and tickborne zoonoses with biological and chemical agents. Bioscience 5:383-394

Pell JK, Eilenberg J, Hajek AE, Steinkraus DC (2001) Biology ecology and pest management potential of Entomophthorales. In: Butt TM, Jackson C, Magan N (eds) Fungi as biocontrol agents: progress, problems and potential. CAB International, Wallingford, pp 71-153

Razmi GR, Ebrahimzadeh E, Aslani MR (2003) A study about tick vectors of bovine theileriosis in an endemic region of Iran. J Vet Med 50:309-310

Roberts DW, Humber RA (1981) Entomogenous fungi. In: Cole GT, Kendrick WB (eds), vol. 2. Academic Press, New York, pp 201-236

Samish M, Gindin G, Alekseev E, Glazer I (2001) Pathogenicity of entomopathogenic fungi to different developmental stages of Rhipicephalus sanguineus (Acari: Ixodidae). J Parasitol $87: 1355-1359$

SAS Institute (2001) SAS/STAT User's Guide: Version 6, 4th edn, vol 1, SAS Institute, Cary Schulze TL, Jordan RA, Hung RW, Krivenko AJ, Schulze JJ, Jordan TM (2001) Effects of an application of granular carbaryl on nontargets forest floor arthropods. J Econ Entomol 10:149154

Tavassoli M, Ownag A, Pourseyed SH, Mardani K (2008) Laboratory evaluation of three strains of the entomopathogenic fungus Metarhizium anisopliae for controlling Dermanyssus gallinae.

Avian Pathol 37:259-263

Watt DM, Walker AR (2000) Pathological effects and reduced survival in Rhipicephalus appendiculatus ticks infected with Theileria parva protozoa. Parasitol Res 86:207-214

Zahid Iqbal R, Song-hua H, Wan-jun C, Abdullah GA, Chen-wen X (2006) Importance of ticks and their chemical and immunological control in livestock. J Zhejiang Univ Sci 7(11):912-921 Zorloni A, Penzhorn BL, Eloff JN (2010) Extract of Calpurnia aurea leaves from Southern Ethiopia attract and immobilise or killed ticks. Vet Parasitol 168(1-2):160-164 